\title{
Type II cGMP-dependent protein kinase inhibits ligand-induced activation of EGFR in gastric cancer cells
}

\author{
LU JIANG, YONGCHANG CHEN, YUEYING LI, TING LAN, MIN WU, YING WANG and HAI QIAN \\ Department of Physiology, School of Medical Science and Laboratory Medicine, \\ Jiangsu University, Zhenjiang, Jiangsu 212013, P.R. China
}

Received June 27, 2013; Accepted January 30, 2014

DOI: $10.3892 / \mathrm{mmr} .2014 .1942$

\begin{abstract}
Our previous data demonstrated that type II cGMP-dependent protein kinase (PKG II) inhibited epidermal growth factor (EGF)-induced MAPK/ERK/JNK-mediated signal transduction through inhibiting the phosphorylation/activation of the epidermal growth factor receptor (EGFR). Since the EGFR also binds with several other ligands as well as EGF, the present study was designed to investigate whether PKG II inhibited transforming growth factor- $\alpha$ (TGF- $\alpha$ ), betacellulin (BTC) and epiregulin (EPR) induced phosphorylation/activation of the EGFR and consequent MAPK/ERK-mediated signaling. The human gastric cancer cell line AGS, was infected with adenoviral constructs encoding cDNA of PKG II (Ad-PKG II) to increase the expression of PKG II and was treated with 8-pCPT-cGMP to activate the kinase. Western blotting was applied to detect the phosphorylation of EGFR and MAPK/ERK. The results demonstrated that treatment with EGF (100 ng/ml, $5 \mathrm{~min}), \mathrm{TGF}-\alpha(100 \mathrm{ng} / \mathrm{ml}, 5 \mathrm{~min})$, BTC (100 $\mathrm{ng} / \mathrm{ml}, 5 \mathrm{~min})$ and EPR $(100 \mathrm{ng} / \mathrm{ml}, 5 \mathrm{~min})$ increased the tyrosine (tyr) 1068 phosphorylation of the EGFR and the threonine (thr) 202/tyr 204 phosphorylation of MAPK/ERK. Infecting the cells with Ad-PKG II and stimulating the kinase with 8-pCPT-cGMP efficiently inhibited the phosphorylation of the EGFR and MAPK/ERK induced by EGF, TGF- $\alpha$, BTC and EPR. The results indicated that PKG II also inhibits the activation of the EGFR caused by diverse ligands of the receptor.
\end{abstract}

\section{Introduction}

Gastric cancer is the fourth most common malignancy and the second leading cause of cancer mortality worldwide (1). Numerous studies indicate that the epithelial growth factor

Correspondence to: Professor Yongchang Chen, Department of Physiology, School of Medical Science and Laboratory Medicine, Jiangsu University, 301 Xuefu Road, Zhenjiang, Jiangsu 212013, P.R. China

E-mail: ycchen54@ujs.edu.cn

Key words: type II cGMP-dependent protein kinase, EGF receptor, ligand, inhibition, gastric cancer cells receptor (EGFR) is overexpressed in various cancer tissues, including gastric cancer, and the majority of human epithelial cancers are marked by a high activity of the EGFR (2-5). Numerous studies have demonstrated that the activation of the EGFR is able to initiate several signal transduction cascades, which lead to the stimulation of cell proliferation, migration, invasion, metastasis, angiogenesis and the inhibition of apoptosis $(6,7)$. Due to its close association with the origin, development, metastasis and invasion of cancer cells, the EGFR was the first growth factor receptor to be proposed as a target for cancer therapy $(8,9)$. Anti-EGFR therapies have been intensively developed for the treatment of multiple cancer types and EGFR inhibitors are currently under investigation.

Type II cGMP-dependent protein kinases (PKG II) is a serine-threonine (ser-thr) kinase. It has been identified for $>30$ years, however certain new functions of this kinase are just being discovered, including its important role in regulating cell proliferation and apoptosis (10-12). Recently, accumulating data demonstrate that PKG II is a potential cancer inhibitor. For example, it was demonstrated that PKG II was able to inhibit the proliferation of human neuroglioma cells and colonic cancer cells $(13,14)$. Data from our laboratory demonstrated that PKG II inhibited the proliferation and migration of gastric cancer cell lines $(15,16)$. Furthermore, we demonstrated that PKG II was able to inhibit EGF initiated signal transduction of the MAPK-mediated pathway by inhibiting the EGF-induced activation of the EGFR in gastric and breast cancer $(17,18)$. Since the mammalian ligands of EGFR include transforming growth factor- $\alpha$ (TGF- $\alpha$ ), heparin-binding EGF-like growth factor, amphiregulin, betacellulin (BTC), epiregulin (EPR) and epigen besides EGF (19), whether PKG II has an inhibitory effect on the activation of EGFR induced by these ligands merits further investigation. The present study was designed to elucidate whether PKG II was able to inhibit the activation of the EGFR induced by EGF, TGF- $\alpha$, BTC and EPR.

\section{Materials and methods}

Cell lines and reagents. The human gastric cancer cell line AGS was purchased from ATCC (Manassas, VA, USA; ATCC ${ }^{\circledR}$ number: CRL-1793 $\left.{ }^{\mathrm{TM}}\right)$. Adenoviral vectors encoding $\beta$-galactosidase (Ad-LacZ) and PKG II (Ad-PKG II) were provided by Dr Gerry Boss and Dr Renate Pilz at the University of California (San Diego, CA, USA). 
Dulbecco's Modified Eagle's Medium (DMEM) and newborn calf serum (NBCS) were purchased from Gibco-BRL (Grand Island, NY, USA). The antibody against PKG II was purchased from Abgent Biotechnology (San Diego, CA, USA). Rabbit anti-EGFR antibody was purchased from Santa Cruz Biotechnology, Inc. (Santa Cruz, CA, USA). Mouse anti-p-EGFR (tyr1068), rabbit anti-p-ERK1/2 (thr 202/tyr 204) and rabbit anti-ERK1/2 antibodies were obtained from Cell Signaling Technology, Inc. (Danvers, MA, USA). The horseradish peroxidase (HRP)-conjugated secondary antibodies were obtained from Jackson ImmunoResearch Laboratories (West Grove, PA, USA). The cellular permeable cGMP analog 8-pCPT-cGMP was acquired from Calbiochem (San Diego, CA, USA). Recombinant human EGF, TGF- $\alpha$, EPR and BTC were obtained from PeproTech (Rocky Hill, NJ, USA). Electrochemiluminescence (ECL) reagents were purchased from Millipore (Billerica, MA, USA). All other reagents used were of analytical grade.

Preparation of the adenoviral vectors. 293A cells were transfected with an adenoviral vector encoding LacZ and PKG II, respectively and cultured for up to 10 days until a cytopathic effect was apparent. The cells and the culture medium were harvested and underwent three freeze-thaw cycles. The supernatant containing adenoviruses (Ad-LacZ and Ad-PKG II) were used to infect new 293A cells to amplify adenoviruses. The amplified adenoviral preparations were titrated and the $\mathrm{pfu} / \mathrm{ml}$ was determined and stored at $-80^{\circ} \mathrm{C}$ until use.

Cell culture and infection with the adenoviral vectors. AGS cells were cultured in DMEM supplied with 10\% NBCS and maintained at $37^{\circ} \mathrm{C}$ in a humidified incubator with $95 \%$ air and $5 \% \mathrm{CO}_{2}$. The medium was changed every 2 days and the cells were sub-cultured at confluence. On the day prior to infection, cells were freshly planted at 70-80\% confluence and infection was performed with a multiplicity of infection of $100 \%$.

Western blotting. Proteins extracted from whole cells were separated by $10 \%$ SDS-PAGE and were transferred onto the PVDF membranes. The primary antibodies were incubated overnight at $4^{\circ} \mathrm{C}$ and the corresponding secondary antibodies were incubated for $1 \mathrm{~h}$ at room temperature, with three washes following each incubation. ECL reagents were used to demonstrate the positive bands on the membrane.

\section{Results}

PKG II inhibits EGF, TGF- $\alpha, B T C$ and EPR induced tyr 1068 phosphorylation of the EGFR. When ligands bind with EGFR, the binding between the ligand and the EGFR causes auto-phosphorylation of the receptor. There are several auto-phosphorylation sites which are connected to different signal transduction pathways. Tyr 1068 is one of the auto-phosphorylation sites of the EGFR and is associated with MAPK/ERK-mediated signaling. In this experiment, we investigated the inhibitory effect of PKG II on the tyr 1068 phosphorylation of the EGFR in differently treated AGS cells by using western blotting. The results demonstrated that the infection with Ad-PKG II caused a clear increase in PKG II expression (Ad-PKG II groups). The treatments with EGF

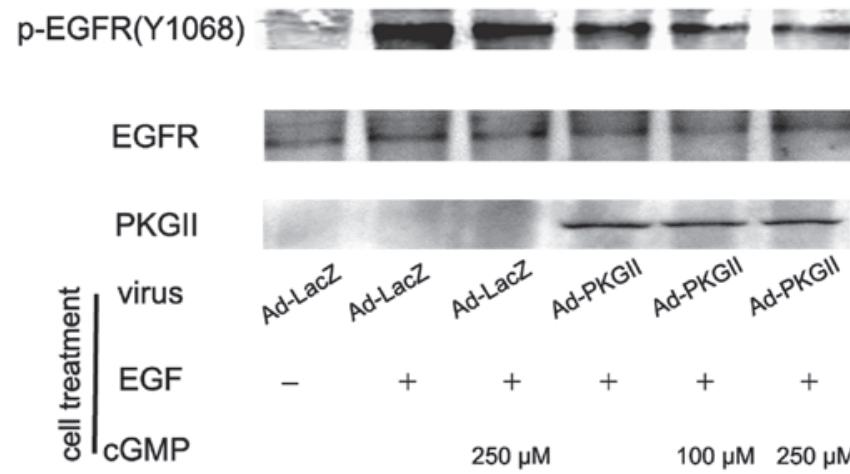

Figure 1. PKG II inhibits EGF-induced tyr 1068 phosphorylation of the EGFR. AGS cells were infected with Ad-LacZ or Ad-PKG II for $48 \mathrm{~h}$ and serum starved overnight. In the Ad-LacZ + EGF and Ad-PKG II + EGF groups, cells were incubated with EGF $(100 \mathrm{ng} / \mathrm{ml})$ for $5 \mathrm{~min}$. In the Ad-LacZ + cGMP + EGF and Ad-PKG II + cGMP + EGF groups, cells were treated with 8-pCPT-cGMP for $1 \mathrm{~h}$ and then with EGF $(100 \mathrm{ng} / \mathrm{ml})$ for 5 min. Cells were harvested and lysed as described in Materials and methods and cell lysate was subjected to western blotting. The results demonstrated that the infection with Ad-PKG II caused a clear increase in PKG II expression (Ad-PKG II groups). EGF treatment induced a marked increase in tyr 1068 phosphorylation of the EGFR (Ad-LacZ + EGF group). Infection with Ad-PKG II + cGMP treatment efficiently inhibited the EGF-induced phosphorylation of the EGFR (Ad-PKG II + cGMP + EGF groups). The results shown are representative of three separate experiments. PKG II, type II cGMP-dependent protein kinase; EGF, epidermal growth factor; Tyr, tyrosine; EGFR, epidermal growth factor receptor; Ad-LacZ, adenoviral vectors encoding $\beta$-galactosidase; Ad-PKG II, adenoviral vectors encoding PKG II; cGMP, cyclic guanosine monophosphate.

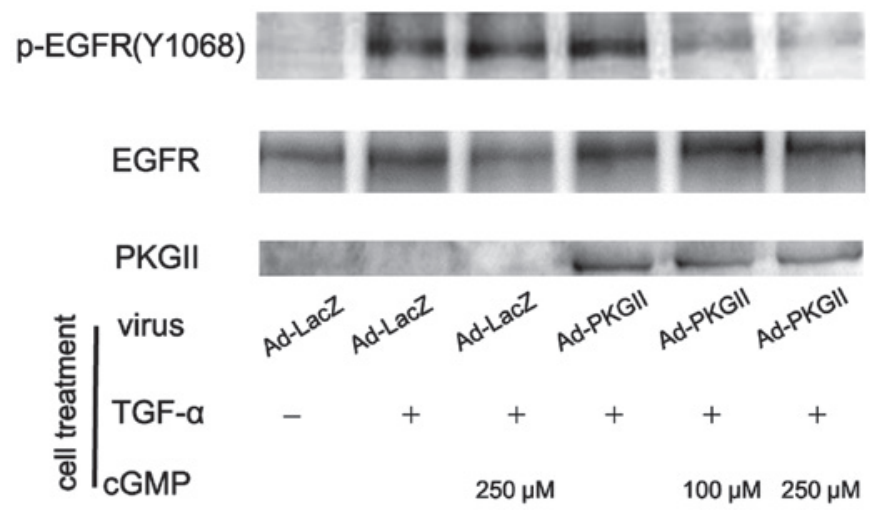

Figure 2. PKG II inhibits TGF- $\alpha$-induced tyr 1068 phosphorylation of the EGFR. AGS cells were treated the same as in Fig. 1, except the EGF was replaced by TGF- $\alpha$. The results demonstrated that TGF- $\alpha$ treatment induced a marked increase in tyr 1068 phosphorylation of the EGFR (Ad-LacZ + TGF- $\alpha$ group). Infection with Ad-PKG II + cGMP treatment efficiently inhibited the TGF- $\alpha$-induced phosphorylation of EGFR (Ad-PKG II + cGMP + TGF- $\alpha$ groups). The results shown are representative of three separate experiments. PKG II, type II cGMP-dependent protein kinase; TGF- $\alpha$, transforming growth factor- $\alpha$; tyr, tyrosine; EGFR, epidermal growth factor receptor; EGF, epidermal growth factor; Ad-LacZ, adenoviral vectors encoding $\beta$-galactosidase; Ad-PKG II, adenoviral vectors encoding PKG II; cGMP, cyclic guanosine monophosphate.

(100 ng/ml, $5 \mathrm{~min})$, TGF- $\alpha$ (100 ng/ml, $5 \mathrm{~min})$, BTC (100 ng/ml, $5 \mathrm{~min}$ ) and EPR (100 $\mathrm{ng} / \mathrm{ml}, 5 \mathrm{~min})$ caused clear increases in tyr 1068 phosphorylation of the EGFR, respectively. In cells infected with Ad-PKG II and stimulated with 8-pCPT-cGMP, the phosphorylation caused by the growth factors was significantly decreased (Fig. 1-4). This indicated that PKG II was 
p-EGFR(Y1068)

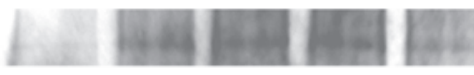

\section{EGFR}

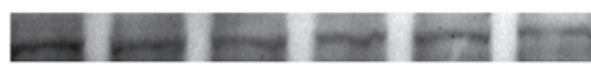

PKGII

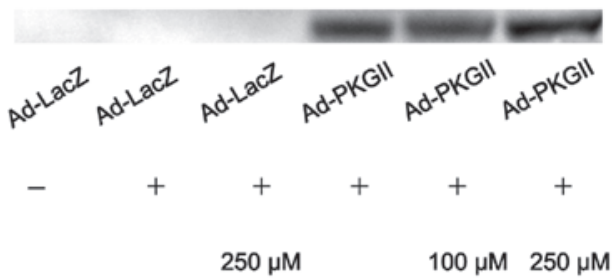

Figure 3. PKG II inhibits BTC-induced tyr 1068 phosphorylation of the EGFR. AGS cells were treated the same as in Fig. 1, except the EGF was replaced by BTC. The results demonstrated that BTC treatment induced a significant increase in tyr 1068 phosphorylation of the EGFR (Ad-LacZ + BTC group). Infection with Ad-PKG II + cGMP treatment efficiently inhibited the BTC-induced phosphorylation of EGFR (Ad-PKG II + cGMP + BTC groups). The results shown are representative of three separate experiments. PKG II, type II cGMP-dependent protein kinase; tyr, tyrosine; EGF, epidermal growth factor receptor; BTC, betacellulin; EGFR, epidermal growth factor receptor; Ad-LacZ, adenoviral vectors encoding $\beta$-galactosidase; Ad-PKG II, adenoviral vectors encoding PKG II; cGMP, cyclic guanosine monophosphate.

\section{p-EGFR(Y1068)}
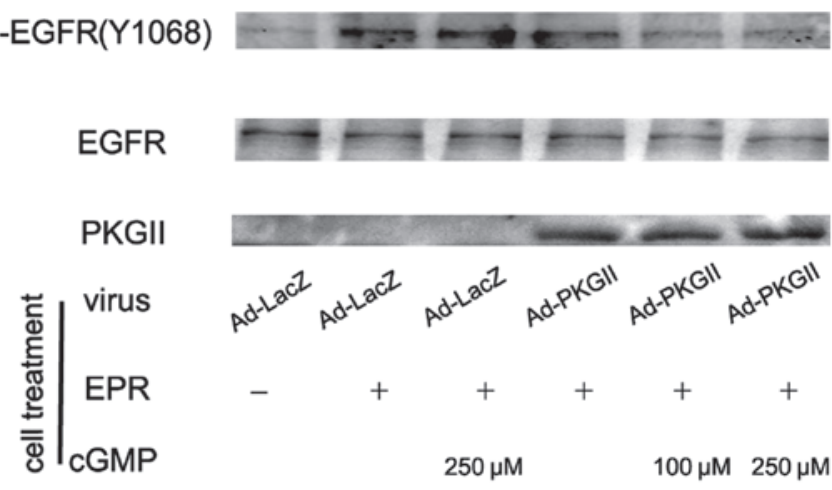

Figure 4. PKG II inhibits EPR-induced tyr 1068 phosphorylation of the EGFR. AGS cells were treated the same as in Fig. 1, except the EGF was replaced by EPR. The results demonstrated that EPR treatment induced a marked increase in tyr 1068 phosphorylation of EGFR (Ad-LacZ + EPR group). Infection with Ad-PKG II + cGMP treatment efficiently inhibited the EPR-induced phosphorylation of the EGFR (Ad-PKG II + cGMP + EPR groups). The results demonstrated are representative of three separate experiments. PKG II, type II cGMP-dependent protein kinase; EPR, epiregulin; EGFR, epidermal growth factor receptor; EGF, epidermal growth factor; tyr, tyrosine; Ad-LacZ, adenoviral vectors encoding $\beta$-galactosidase; Ad-PKG II, adenoviral vectors encoding PKG II; cGMP, cyclic guanosine monophosphate.

able to inhibit EGF, TGF- $\alpha$, BTC and EPR-induced tyr 1068 phosphorylation/activation of the EGFR.

$P K G$ II inhibits the ERK activation induced by EGF, TGF- $\alpha$, $B T C$ and EPR. Activation of the EGFR is able to initiate several signal transduction pathways. Among them, the MAPK/ERK-mediated pathway is the one closely associated with the proliferation and differentiation of cells. MAPK/ERK is the key component of this pathway and phosphorylation at thr 202 and tyr 204 residues of ERK1 and thr 185 and tyr 187 residues of ERK2 is required for full enzymatic activation. In this experiment, the antibody against p-ERK1/2
A

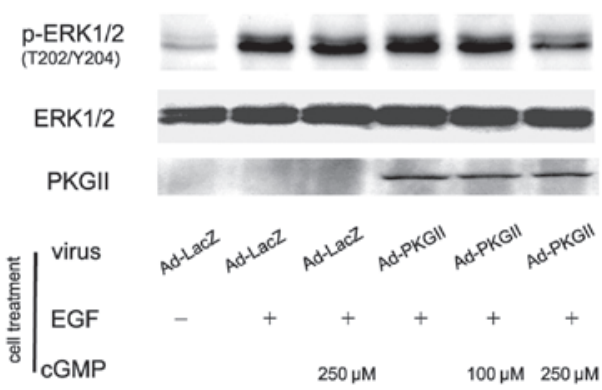

B

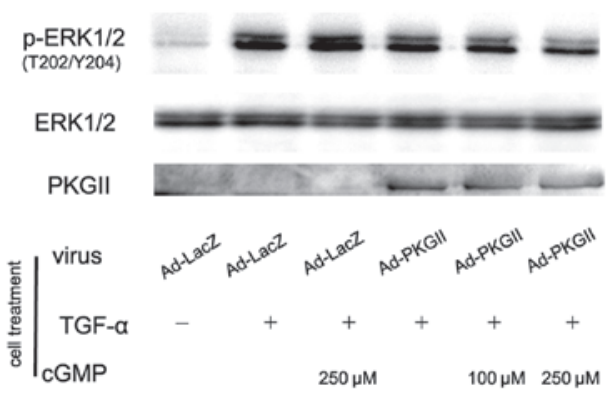

C

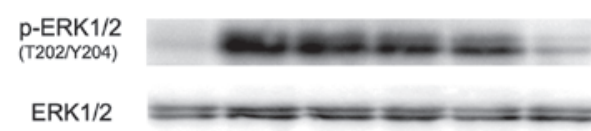

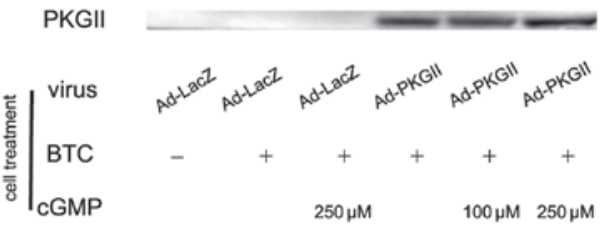

D

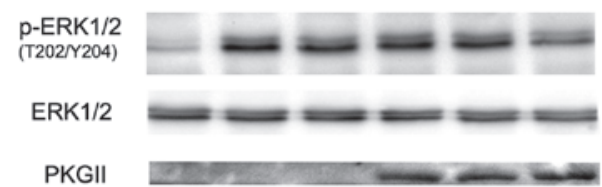

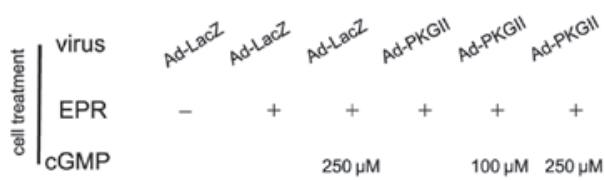

Figure 5. PKG II inhibits the phosphorylation of ERK induced by EGF, TGF- $\alpha$, BTC and EPR, respectively. AGS cells were infected with Ad-PKG II for $48 \mathrm{~h}$, serum starved overnight, incubated with 8-pCPT-cGMP for $1 \mathrm{~h}$ and then stimulated with EGF $(100 \mathrm{ng} / \mathrm{ml})$, TGF- $\alpha(100 \mathrm{ng} / \mathrm{ml})$, BTC $(100 \mathrm{ng} / \mathrm{ml})$ and EPR $(100 \mathrm{ng} / \mathrm{ml})$, respectively for $5 \mathrm{~min}$. Western blotting was applied to detect the phosphorylation of ERK. Within $5 \mathrm{~min}$ after adding the ligands to culture medium, phosphorylation of ERK significantly increased. (A) Ad-LacZ + EGF group; (B) Ad-LacZ + TGF- $\alpha$ group; (C) Ad-LacZ + BTC group; (D) Ad-LacZ + EPR group. The phosphorylation was inhibited by pre-infecting the cells with Ad-PKG II and stimulating the enzyme with 8-pCPT-cGMP. (A) Ad-PKG II + cGMP + EGF groups; (B) Ad-PKG II + cGMP + TGF- $\alpha$ groups; (C) Ad-PKG II + cGMP + BTC groups; (D) Ad-PKG II + cGMP + EPR groups. The results shown are representative of three separate experiments. PKG II, type II cGMP-dependent protein kinase; ERK, extracellular signal-regulated kinase; EGF, epidermal growth factor; TGF- $\alpha$, transforming growth factor- $\alpha$, BTC, betacellulin; EPR, epiregulin; Ad-LacZ, adenoviral vectors encoding $\beta$-galactosidase; Ad-PKG II, adenoviral vectors encoding PKG II; cGMP, cyclic guanosine monophosphate. 
(thr 202/tyr 204) was applied in western blotting to detect the dual phosphorylation of ERK. The results demonstrated that within 5 min after adding EGF $(100 \mathrm{ng} / \mathrm{ml})$, TGF- $\alpha$ $(100 \mathrm{ng} / \mathrm{ml})$, BTC $(100 \mathrm{ng} / \mathrm{ml})$ and EPR $(100 \mathrm{ng} / \mathrm{ml})$ to cell culture medium, phosphorylation of ERK1/2 in AGS cells significantly increased and the phosphorylation was inhibited by pre-infecting the cells with Ad-PKG II and activating the enzyme with 8-pCPT-cGMP (Fig. 5).

\section{Discussion}

The EGFR belongs to the ErbB receptor tyrosine kinase family, which includes erbB1 (EGFR), erbB2 (HER2), erbB3 (HER3) and erbB4 (HER4). EGFR is a $170 \mathrm{kDa}$ protein that consists of an extracellular domain, a transmembrane domain and a cytoplasmic domain (20). The activation of EGFR depends on its binding with ligands and the consequent dimerization and auto-phosphorylation of the receptor. When the EGFR is activated, it is able to recruit effector proteins to its phosphorylated C-terminal sub-domain and initiate the effector protein-mediated signaling pathways. Increased expression and activation of the EGFR and its ligands are causally associated with the progression of gastric cancer and poor prognosis $(21,22)$.

The ligands of the EGFR include EGF, TGF- $\alpha$, BTC and EPR. They are structurally and functionally related proteins and are able to bind and activate the EGFR. These ligands and the consequent EGFR signaling are important in regulating the proliferation, survival, migration and differentiation of various cancer cells (19).

EGF is thought to be involved in neoplastic formation and the progression of gastric cancer. EGF is a single polypeptide built of 53 amino acids and is important in intercellular interactions. Co-operation between the EGF of one cell and the receptor (EGFR) on the adjacent cell leads to certain biological effects, including migration, growth or morphological changes in the cell (23). Normally, EGF stimulates the growth or exerts a trophic effect in numerous tissues and is important in the proliferation, differentiation and maturation of embryonic cells. However, EGF and the EGFR, apart from the key role they play in physiological development, also take part in neoplastic transformation. Increased expression of EGF and the EGFR have been observed in various malignancies, including gastric carcinoma (24).

TGF- $\alpha$ is produced in macrophages, brain cells and keratinocytes, and induces epithelial development. It shares only $\sim 30 \%$ structural homology with EGF, however it is also able to bind to the EGF receptor with similar affinity and signal via the EGFR (25). TGF- $\alpha$ is upregulated in certain types of human cancer. Several studies demonstrated that overexpression of growth factors in the gastric mucosa was implicated in the pathogenesis of gastric cancer (26) and gastric cancer cells grew in response to EGF/TGF- $\alpha$ activation of the EGFR in an autocrine loop (27).

BTC was originally identified in conditioned media from a pancreatic $\beta$-cell tumor line $(28,29)$. There is evidence confirming that BTC is a potent mitogen for vascular smooth muscle cells and retinal pigment epithelial cells $(28,30)$. BTC has also been detected in a variety of tumor-derived cell lines and tumors in situ $(30,31)$.
EPR was initially isolated from the conditioned medium of mouse tumorigenic fibroblasts NIH3T3/clone T7 cells (32). There are extremely low expression levels of EPR transcripts in the majority of normal tissues except in the peripheral blood monocytes and the uterus $(33,34)$, however several cancer cells and cytokine-induced smooth muscle cells overexpress EPR mRNA (33). It is known that EPR is a more potent mitogen than EGF for several types of normal cells $(32,35)$ and is important in the development and progression of epithelial malignancies in an autocrine/paracrine manner (36).

For a long time, PKG II has been implicated in several physiological functions, including intestinal secretion, bone growth and learning and memory. However, certain new functions of PKG II are being discovered recently, including the participation of PKG II in mechanotransduction in osteoblasts and the role of PKG II in the regulation of sodium channels $(37,38)$. More importantly, accumulating data indicated that PKG II may be a potential cancer suppressor because it is critical in the proliferation, migration and apoptosis of cancer cells $(15,16,18)$. Our previous results demonstrated that PKG II was able to inhibit EGF-induced tyr 1068 phosphorylation of the EGFR in gastric cancer and breast cancer cells (16-18), raising the question of whether PKG II is able to inhibit tyr 1068 phosphorylation of the EGFR induced by other ligands. Results in the present study not only demonstrated that EGF, TGF- $\alpha$, BTC and EPR were able to induce tyr 1068 phosphorylation of EGFR and thr 202 and tyr 204 phosphorylation of ERK, but also confirmed that PKG II was able to inhibit these phosphorylations. This revealed that PKG II has a wide-ranging inhibitory effect on the activation of the EGFR induced by diverse ligands and adds further evidence to support PKG II as a potential cancer suppressor.

\section{Acknowledgements}

This study was supported by the National Natural Science Foundation of China (no. 81272755, no. 31040002, no. 81201959 and no. 31100974) and the Innovation Grant of Jiangsu University. We thank Dr Gerry Boss and Dr Renate Pilz, University of California (San Diego, CA, USA) for providing the adenoviral constructs.

\section{References}

1. Shah MA and Schwartz GK: Treatment of metastatic esophagus and gastric cancer. Semin Oncol 31: 574-587, 2004.

2. Becker JC, Muller-Tidow C, Serve H, et al: Role of receptor tyrosine kinases in gastric cancer: new targets for a selective therapy. World J Gastroenterol 12: 3297-3305. 2006.

3. Arnold D, Peinert S, Voigt W, et al: Epidermal growth factor receptor tyrosine kinase inhibitors: present and future role in gastrointestinal cancer treatment: a review. Oncologist 11: 602-611, 2006.

4. Johnston JB, Navaratnam S, Pitz MW, et al: Targeting the EGFR pathway for cancer therapy. Curr Med Chem 13: 3483-3492, 2006.

5. Astsaturov I, Cohen RB and Harari PM: EGFR-targeting monoclonal antibodies in head and neck cancer. Curr Cancer Drug Targets 6: 691-710, 2006.

6. Oda K, Matsuoka Y, Funahashi A and Kitano H: A comprehensive pathway map of epidermal growth factor receptor signaling. Mol Syst Biol 1: 2005.0010, 2005.

7. Yarden Y and Shilo BZ: SnapShot: EGFR signaling pathway. Cell 131: 1018, 2007.

8. Arteaga CL: Overview of epidermal growth factor receptor biology and its role as therapeutic taget in human neoplasia. Semin Oncol 29: 3-9, 2002. 
9. Krozely P: Epidermal growth factor receptor tyrosine kinase inhibitors: evolving role in the treatment of solid tumors. Clin J Oncol Nurs 8: 163-168, 2004.

10. Cook AL and Haynes JM: Protein kinase G II-mediated proliferative effects in human cultured prostatic stromal cells. Cell Signal 16: 253-261, 2004.

11. Swartling FJ,Ferletta M,Kastemar M, et al: Cyclic GMP-dependent protein kinase II inhibits cell proliferation, Sox9 expression and Akt phosphorylation in human glioma cell lines. Oncogene 28: 3121-3131, 2009.

12. Fallahian F, Karami-Tehrani F, Salami S, et al: Cyclic GMP induced apoptosis via protein kinase $\mathrm{G}$ in oestrogen receptor-positive and -negative breast cancer cell lines. FEBS J 278: 3360-3369, 2011.

13. Swartling FJ,Ferletta M,Kastemar M, et al: Cyclic GMP-dependent protein kinase II inhibits cell proliferation, Sox9 expression and Akt phosphorylation in human glioma cell lines. Oncogene 28: 3121-3131, 2009.

14. Wang R, Kwon IK, Thangaraju M, et al: Type 2 cGMP-dependent protein kinase regulates proliferation and differentiation in the colonic mucosa. Am J Physiol Gastrointest Liver Physiol 303: G209-G219, 2012.

15. Chen YC, Ren F, Sang JR, et al: Type II cGMP-dependent protein kinase inhibits proliferation of the gastric cancer cell line BGC-823. Mol Med Rep 3: 361-366, 2010.

16. Jiang L, Lan T, Chen Y, et al: PKG II inhibits EGF/EGFR-induced migration of gastric cancer cells. PLoS One 8: e61674, 2013.

17. Wu Y, Chen Y, Qu R, et al: Type II cGMP-dependent protein kinase inhibits EGF-triggered signal transduction of the MAPK/ERK-mediated pathway in gastric cancer cells. Oncol Rep 27: 553-558, 2012.

18. Lan T, Chen Y, Sang J, et al: Type II cGMP-dependent protein kinase inhibits EGF-induced MAPK/JNK signal transduction in breast cancer cells. Oncol Rep 27: 2039-2044, 2012.

19. Harris RC, Chung E and Coffey RJ: EGF receptor ligands. Exp Cell Res 284, 2-13, 2003.

20. Prigent SA and Lemoine NR: The type I (EGFR-related) family of growth factor receptors and their ligands. Prog Growth Factor Res 4: 1-24, 1992.

21. Barnard JA, Beauchamp RD, Russell WE, et al: Epidermal growth factor-related peptides and their relevance to gastrointestinal pathophysiology. Gastroenterology 108: 564-580, 1995.

22. D'Agnano I, D'Angelo C, Savarese A, et al: DNA ploidy, proliferative index, and epidermal growth factor receptor: expression and prognosis in patients with gastric cancers. Lab Invest 72 432-438, 1995.

23. Wells A: EGF receptor. Int J Biochem Cell Biol 31: 637-643, 1999.

24. Takemura S, Yashiro M, Sunami T, et al: Novel models for human scirrhous gastric carcinoma in vivo. Cancer Sci 95: 893-900, 2004
25. Wang C, Lv X, Jiang C, et al: Transforming growth factor alpha $(\mathrm{TGF} \alpha)$ regulates granulosa cell tumor $(\mathrm{GCT})$ cell proliferation and migration through activation of multiple pathways. PLoS One 7: e48299, 2012.

26. Dias A, Garcia C, Majewski M, et al: Gastric juice prostaglandins and peptide growth factors as potential markers of chronic atrophic gastritis, intestinal metaplasia and gastric cancer: their potential clinical implications based on this pilot study. Dig Dis Sci 56: 3220-3225, 2011

27. Yoshida K, Kyo E, Tsujino T, et al: Expression of epidermal growth factor, transforming growth factor-alpha and their receptor genes in human gastric carcinomas; implication for autocrine growth. Jpn J Cancer Res 81: 43-51, 1990.

28. Sasada R, Ono Y, Taniyama, Y, et al: Cloning and expression of cDNA encoding human betacellulin, a new member of the EGF family. Biochem Biophys Res Commun 190: 1173-1179, 1993.

29. Dunbar AJ and Goddard C: Structure-function and biological role of betacellulin. Int J Biochem Cell Biol 32: 805-815, 2000.

30. Shing Y, Christofori G, Hanahan D, et al: Betacellulin: a mitogen from pancreatic beta cell tumors. Science 259: 1604-1607, 1993.

31. Seno M, Tada H, Kosaka M, et al: Human betacellulin, a member of the EGF family dominantly expressed in pancreas and small intestine, is fully active in a monomeric form. Growth Factors 13: 181-191, 1996.

32. Toyoda H, Komurasaki T, Uchida D, et al: Epiregulin. A novel epidermal growth factor with mitogenic activity for rat primary hepatocytes. J Biol Chem 270: 7495-7500, 1995.

33. Toyoda H, Komurasaki T, Uchida D et al: Distribution of mRNA for human epiregulin, a differentially expressed member of the epidermal growth factor family. Biochem J 326: 69-75, 1997.

34. Das SK, Das N, Wang J, et al: Expression of betacellulin and epiregulin genes in the mouse uterus temporally by the blastocyst solely at the site of its apposition is coincident with the "window" of implantation. Dev Biol 190: 178-190, 1997.

35. Komurasaki T, Toyoda H, Uchida D, et al: Mechanism of growth promoting activity of epiregulin in primary cultures of rat hepatocytes. Growth Factors 20: 61-69, 2002.

36. Shirakata Y, Komurasaki T, Toyoda H, et al: Epiregulin, a novel member of the epidermal growth factor family, is an autocrine growth factor in normal human keratinocytes. J Biol Chem 275: $5748-5753,2000$

37. Rangaswami H, Marathe $\mathrm{N}$, Zhuang S, et al: Type II cGMP-dependent protein kinase mediates osteoblast mechanotransduction. J Biol Chem 284: 14796-14808, 2009.

38. Nie HG, Chen L, Han DY, et al: Regulation of epithelial sodium channels by cGMP/PKGII. J Physiol 587: 2663-2676, 2009. 